Article

\title{
Unravelling the Potency of Activated Carbon Powder Derived from Cultivated Marine Microalgae as a Promising Filler in Mixed Matrix Membranes
}

\author{
Agung Sukoyo ${ }^{1}$, Gunomo Djoyowasito ${ }^{1}$ and Yusuf Wibisono ${ }^{2,3, *(D)}$ \\ 1 Department of Agricultural Engineering, Brawijaya University, Malang 65145, Indonesia; \\ ohmagung@gmail.com (A.S.); djoyowasitogunomo@yahoo.com (G.D.) \\ 2 Department of Bioprocess Engineering, Brawijaya University, Malang 65145, Indonesia \\ 3 MILI Water Research Institute, PO Box 301 ML, Malang 65145, Indonesia \\ * Correspondence: Y_Wibisono@ub.ac.id; Tel.: +62-341-571-708
}

Received: 30 December 2018; Accepted: 10 April 2019; Published: 16 April 2019

\begin{abstract}
Activated carbon-filled mixed matrix membranes were commonly used to enhance the separation performance of liquid or gas separation processes. Activated carbon is traditionally derived from agricultural crops such as coconut shells or wood biomass. Marine microalgae however have a great potential to produce powdered activated carbon. In this study, marine microalgae Chlorella vulgaris have been evaluated for their carbon content, and the $16.09 \%$ carbon content has potential to be employed as a raw material in manufacturing activated carbon powder. Dry microalgae were carbonized at a temperature of $500{ }^{\circ} \mathrm{C}$ for $30 \mathrm{~min}$, at a constant increment rate of temperature of $10^{\circ} \mathrm{C}$ per minute to produce microalgae charcoal. Chemically-based activation treatments using $\mathrm{H}_{3} \mathrm{PO}_{4}$ and $\mathrm{ZnCl}_{2}$ with concentrations of $10 \%, 30 \%$, and $50 \%$, respectively, assisted by microwave irradiation, have been used to prepare activated carbon. The properties of activated carbon powder were analyzed including yields, ash content, volatile substances, pure activated carbon content, absorption of iodine solution, surface area, and imaging of activated carbon using SEM-EDX. The best treatment characteristics were obtained using $\mathrm{H}_{3} \mathrm{PO}_{4}$ at a concentration of $50 \%$ with characteristics of $19.47 \%$ yield, $11.19 \%$ ash content, $31.92 \%$ volatile content, $56.89 \%$ pure activated carbon, $325.17 \mathrm{mg} \mathrm{g}^{-1}$ iodine absorption, and $109.273 \mathrm{~m}^{2} \mathrm{~g}^{-1}$ surface area based on the Brunauer-Emmett-Teller (BET) method, as well as a 5.5-nm average pore diameter. The SEM-EDX imaging results showed the formation of micropores on the surface of activated carbon, with carbon content reaching $72.31 \%$; however, impurities could decrease the surface area and reduce the absorption performance of microalgae activated carbon.
\end{abstract}

Keywords: activated carbon; microalgae; Chlorella vulgaris; mixed matrix membranes; microwave

\section{Introduction}

Biomass, especially from agricultural and aquacultural products, has become an important source for manufacturing biofuels, bioproducts, and biomaterials were are used for various industrial purposes [1-3]. Microalgae, among others, have received much attention because these microscopic photosynthetic organisms are promising sources of biomass and have several advantages over land-based crops [4]. Microalgae produced higher yields of lipids as raw material for biodiesel [5]. Microalgae are the fastest growing photosynthetic organisms. Besides consuming $\mathrm{CO}_{2}$ compounds and $\mathrm{N}$ elements from the atmosphere, microalgae are also one of the most important producers of oxygen on Earth [6]. When compared with terrestrial plants, microalgae have higher photosynthetic activity, faster growth rates, and better $\mathrm{CO}_{2}$ fixation efficiency, which is around 10-50-times [7]. Microalgae 
contain almost $50 \%$ of carbon on a dry weight basis, and theoretically, every $1 \mathrm{~kg}$ of dry algal biomass can absorb about $1.83 \mathrm{~kg} \mathrm{CO}_{2}$ [8].

Referring to the microalgae biomass potential, which contains many important elements and can be cultivated rapidly, microalgae become an important source of food ingredients, health care products, biofuels, animal or aquaculture feeds, pigments, and cosmetics $[9,10]$. Moreover, recent studies concerning the utilization of microalgae biomass also focused on the utilization of microalgae biomass for biohydrogen production, biogas, bio-crude, and biochar by fermentation, anaerobic processes, liquefaction, and pyrolysis [11-16]. Yet, there is a great potential of microalgae that is not widely evaluated, which is the use of microalgae as an activated carbon source. Research on the production of microalgae-based activated carbon is barely found in the literature, despite its immense potential.

Activated carbon is a porous carbon material, commonly used as an absorber for various industrial purposes, from chemicals production, to automotive manufacture, to food industries. In separation processes, activated carbon could be used to enhance membrane separation performance. Membrane filtration is effectively replacing conventional, complicated, and costly separation processes. However, membrane processes also possess serious hindrances such as fouling [17,18]. Activated carbon impregnated in membrane materials could improve mechanical strength, enhance rejection, and minimize fouling [19]. The aforementioned concept is commonly defined as composite or mixed matrix membranes [20]. As a membrane filler, activated carbon promoted the enhancement of the membrane surface hydrophilicity in a polyethersulfone (PES) nanofiltration membrane for sulfate and copper removal [21] and a nanofiber polyvinylidene fluoride-co-hexafluoropropylene (PVDF-HFP) membrane for direct contact membrane distillation [22]. Activated carbon-embedded membranes also helped with reducing fouling in polyvinylidene fluoride (PVDF) ultrafiltration for water treatment [23] and for treatment of dairy effluent [24]. Not only applicable to liquid separation, but a mixed matrix membrane with activated carbon filler also improved the selectivity of $\mathrm{CO}_{2} / \mathrm{CH}_{4}$ separation [25], $\mathrm{C}_{3} \mathrm{H}_{8} / \mathrm{CH}_{4}$ separation [26], $\mathrm{CO}_{2} / \mathrm{CH}_{4}, \mathrm{H}_{2} / \mathrm{CH}_{4}, \mathrm{O}_{2} / \mathrm{N}_{2}$ separation [27], as well as fuel desulfuration by pervaporation [28].

Obviously, activated carbon enhances membrane filtration performance. The biomass source of activated carbon, however, is still limited to terrestrial crop biomass, such as coconut shell, palm shell, wood, peat, and even bituminous coal [29]. Therefore, the evaluation of activated carbon derived from non-crop biomass is essential. This study evaluated the synthesis of activated carbon from microalgae Chlorella vulgaris biomass. Following the carbonization stage, chemical activation methods assisted by microwave irradiation were used to optimize the formation of activated carbon pores with a shorter time compared to activation using conventional heating [30]. This study is aimed at the utilization of microalgae-based activated carbon powder to improve separation performance of polymer membrane, especially for liquid and gas separation.

\section{Materials and Methods}

\subsection{Materials}

Microalgae Chlorella vulgaris used as raw material for activated carbon synthesis in this study was cultivated and harvested at the Brackish Aquaculture and Aquaculture Center, Situbondo, Indonesia. Microalgae biomass was cultivated for 7 days in an open pond with the addition of Walne fertilizer with a mixture of $\mathrm{KNO}_{3}, \mathrm{NaH}_{2} \mathrm{PO}_{4}, \mathrm{Na}_{2} \mathrm{EDTA}$, and $\mathrm{FeCl}_{3}$ to provide adequate nutrients for microalgae growth. Following the harvesting stage using the flocculation method, microalgae biomass was dried using an oven at $60^{\circ} \mathrm{C}$ for $8 \mathrm{~h}$, and the drying continued with sunlight to obtain microalgae with a $4.47 \%$ moisture content for Chlorella vulgaris powder. Carbonization of dry microalgae biomass was carried out at $500{ }^{\circ} \mathrm{C}$ with a heating rate of $10{ }^{\circ} \mathrm{C} \cdot \mathrm{min}^{-1}$ and a holding time of $30 \mathrm{~min}$. Microalgae charcoal size produced from the carbonization process was equal to $149 \mu \mathrm{m}$ as measured by a wire mesh. Then, $8 \mathrm{~g}$ of microalgae charcoal samples were immersed 
in $30 \mathrm{~mL}$ of $\mathrm{H}_{3} \mathrm{PO}_{4}$ and $\mathrm{ZnCl}_{2}$ solution with concentrations of $10 \%, 30 \%$, and $50 \%$, respectively. Soaking was carried out for $24 \mathrm{~h}$, followed by 600-W microwave irradiation for $8 \mathrm{~min}$ (equivalent to an estimated temperature of $150-180^{\circ} \mathrm{C}$ ).

Following the activation process, the activated carbon produced was cleaned by washing using $1 \mathrm{M}$ heated $\mathrm{HCl}$ and subsequently washed using distilled water until the $\mathrm{pH}$ of the activated carbon was nearly 7.0. The washed activated carbon obtained was then dried using an oven at $105^{\circ} \mathrm{C}$ for $24 \mathrm{~h}$ until dry activated carbon was obtained. Each series of experiments in the study was repeated three times. The evaluated parameters included ash content, volatile substances, pure activated carbon content, iodine solution absorption, surface area, pore structure, and element composition.

\subsection{Ash Content}

The ash content measurement was done according to the standard ASTM D 2866-70. Samples of activated carbon of $1 \mathrm{~g}$ were taken from each treatment, then put into a porcelain crucible. Samples and the porcelain crucible were put into a furnace with a temperature of $750{ }^{\circ} \mathrm{C}$ for $1 \mathrm{~h}$. The porcelain crucible was taken and cooled, then the final sample mass was weighed. The heating process with a furnace was repeated until a constant ash weight was obtained. The value of ash content was calculated by Equation (1) as follows:

$$
A_{C}=\frac{m_{0}}{m_{1}} \times 100 \%
$$

where $A_{c}$ is the ash content (\%); $m_{0}$ is the initial mass (g); $m_{1}$ is the final mass (g).

\subsection{Volatile Matter Content}

The volatile matter content measurement was done based on ISO 562-1981. Samples of activated carbon of $1 \mathrm{~g}$ were taken from each treatment, then put into a porcelain crucible. Samples and the porcelain crucible were heated at $950{ }^{\circ} \mathrm{C}$ for $10 \mathrm{~min}$ using a furnace. The porcelain crucible was taken and cooled, then the final mass of the sample was weighed. The value of the vaporized substance was calculated using Equation (2) as follows:

$$
V_{D}=\left[\frac{a-b}{a}\right] \times 100 \%
$$

where $V_{D}$ is volatile matter content (\%); $a$ is the initial mass of the sample before heating $(\mathrm{g}) ; b$ is the final sample mass after heating $(\mathrm{g})$.

\subsection{Pure Activated Carbon Content}

The calculation of bound carbon levels or levels of pure activated carbon was the amount of carbon resulting from the combustion process without the presence of other substances contained in carbon, such as ash and other substances that are still attached to the surface of activated carbon. Pure activated carbon levels can be calculated using Equation (3) as follows:

$$
C_{P A C}=100 \%-\left(A_{c}+V_{D}\right)
$$

where $C_{P A C}$ is pure activated carbon content (\%).

\subsection{Iodine Absorption}

The iodine absorption measurement were done based on American Water Works Association standard method AWWA B 600-78. Samples of activated carbon of $0.25 \mathrm{~g}$ were weighed and then put into an Erlenmeyer tube. A standard Iodine solution of $0.1 \mathrm{~N}$ was added to $25 \mathrm{~mL}$. The mixture was stirred for $15 \mathrm{~min}$, then filtered. As much as $10 \mathrm{~mL}$ of this filtrate were put into another Erlenmeyer tube, then the filtrate was titrated with $0.1 \mathrm{~N}$ sodium thiosulfate until turning pale yellow. An indicator of $1 \%$ starch solution was added, and the titration continued until the filtrate became clear. The amount 
of sodium thiosulfate solution used must be recorded, to calculate the value of iodine absorption, by using Equation (4) below:

$$
I A N=\left[\frac{10-\left[\frac{B \times C}{D}\right] \times 12.693 \times 2.5}{W}\right]
$$

where $I A N$ is the iodine number $(\mathrm{mg} / \mathrm{g}) ; B$ is the volume of the total sodium thiosulfate used during titration $(\mathrm{mL}) ; C$ is the normality of sodium thiosulfate $(\mathrm{N}) ; D$ is the normality of iodine $(\mathrm{N}) ; W$ is the mass of activated carbon (g); 12.693 is the amount of iodine that corresponds to $1 \mathrm{~mL}$ of $0.1 \mathrm{~N}$ sodium thiosulfate solution.

\subsection{Surface Area}

Surface area was measured based on the Brunauer-Emmett-Teller (BET) method by using the Nova 1200e Surface Area Analyzer (Quantachrome Instruments). External or non-microporous area and micropore volume $(\mathrm{Vp})$ were calculated based on nitrogen gas adsorption. Before measuring its surface area, the sample mass was weighed first so that the surface area could be known every $1 \mathrm{~g}$ of sample. Details of the measurement were described elsewhere [31].

\subsection{Pore Imaging and Elemental Composition}

Investigation of the morphology of activated carbon and elemental composition was carried out using the SEM-EDX Inspect 24 (FEI Ltd., Hillsboro, OR, USA). SEM testing was carried out to determine the surface and pore patterns of activated carbon formed, while EDX testing was carried out to analyze the composition of activated carbon elements. Surface functional groups of activated carbon were analyzed using an FTIR spectrophotometer (8400S/Shimadzu, Kyoto, Japan).

\section{Results}

\subsection{Characteristics of Biomass Microalgae Chlorella vulgaris Raw}

The composition of raw materials is an important factor in the manufacture of activated carbon, because it can affect the pore arrangement and the characteristics of the activated carbon produced. As shown in Table 1, the biomass composition of Chlorella vulgaris microalgae consisted of various elements; the presence of carbon content detected in the Chlorella vulgaris biomass indicates that this biomass has the potential to be used as raw material for activated carbon even though the amount was relatively small. Other elements were also detected in the microalgae Chlorella vulgaris sample, namely $\mathrm{Na}$ and $\mathrm{Cl}$ elements; these elements are a salt-forming element, which is generally contained in brackish water used as a medium for the cultivation of microalgae. In addition, the presence of other elements contained in microalgae biomass in small amounts such as $\mathrm{Mg}, \mathrm{P}, \mathrm{S}, \mathrm{Ca}$, and $\mathrm{Si}$ are thought to originate from the standard fertilizer composition used to nourish the growth of microalgae containing $\mathrm{KNO}_{3}, \mathrm{NaH}_{2} \mathrm{PO}_{4}, \mathrm{Na}_{2} \mathrm{EDTA}$, and $\mathrm{FeCl}_{3}$ and direct contact between microalgae culture media with the external environment, because microalgae were developed using the open pond method, not by using a photobioreactor, so that contamination from the outside environment was possible. 
Table 1. Comparison of the elemental composition of microalgae Chlorella vulgaris dry raw mass powder, charcoal, and activated carbon.

\begin{tabular}{|c|c|c|c|c|}
\hline \multirow{2}{*}{ Element Content } & \multicolumn{4}{|c|}{ Elemental Composition (wt\%) } \\
\hline & Dry Raw Powder & Charcoal & Activated $\mathrm{ZnCl}_{2} \mathbf{1 0} \%$ & Activated $\mathrm{H}_{3} \mathrm{PO}_{4} 50 \%$ \\
\hline $\mathrm{C}$ & 16.09 & 27.81 & 23.53 & 72.31 \\
\hline $\mathrm{O}$ & 25.78 & 28.54 & 26.57 & 19.79 \\
\hline $\mathrm{Na}$ & 15.99 & 8.42 & - & - \\
\hline $\mathrm{Mg}$ & 14.24 & 15.63 & 5.43 & 0.21 \\
\hline $\mathrm{P}$ & 0.60 & 0.59 & 3.12 & - \\
\hline$S$ & 0.58 & - & 1.00 & - \\
\hline $\mathrm{Cl}$ & 23.87 & 15.55 & 0.58 & - \\
\hline $\mathrm{Ca}$ & 1.64 & 2.10 & 0.69 & - \\
\hline $\mathrm{Zr}$ & 1.03 & 1.36 & 0.88 & - \\
\hline $\mathrm{Si}$ & 0.18 & - & 0.50 & 7.69 \\
\hline $\mathrm{Zn}$ & - & - & 37.69 & - \\
\hline $\mathrm{Au}$ & - & - & - & - \\
\hline
\end{tabular}

\subsection{Characteristics of Microalgae Chlorella vulgaris Charcoal}

Charcoal produced from the carbonate process was dark black, had a brittle structure, did not smell, and did not dissolve in water. The yield obtained from the carbonization process of dried microalgae powder to become microalgae charcoal was $57.27 \%$, indicating that carbonization had a large influence on the yield of charcoal obtained. This condition was due to some volatile substances disappearing along with the carbonization process. Further oxidation also occurred optimally without the absence of an inert gas that functions as an inhibitor of the oxidation reaction during the carbonization process. Pyrolysis of biomass Chlorella vulgaris will undergo three stages: heating at room temperature up to $180^{\circ} \mathrm{C}$; at this stage, steam will be released from the carbon matrix and will experience a mass loss of $6.87 \%$. In the second stage at a temperature of $185-596^{\circ} \mathrm{C}$, devolatilization and pyrolysis occurred; at this stage, the weight loss was clearly seen compared to the first stage, and the reaction was obtained by increasing the speed with the maximum temperature as $307^{\circ} \mathrm{C}$; at this stage, the biomass will lose $55 \%$. In the third stage with a temperature of $600-800{ }^{\circ} \mathrm{C}$, solid charcoal material occurred slowly with constant degradation after the devolatilization process was complete [32].

The results of SEM-EDX testing showed that the elemental components contained in the microalgae charcoal were not much different from the components of the microalgae dry powder, as shown in Table 1, which still contained elements of $\mathrm{C}, \mathrm{O}, \mathrm{Na}, \mathrm{Mg}, \mathrm{Cl}$, and other elements in very small amounts. The existence of this carbonization process caused an increase in the average weight of carbon elements in carbonized charcoal compared to dry microalgae powder, which rose to $27.81 \%$ from the original $16.09 \%$. The increase in elemental weight also occurred in elements $\mathrm{O}, \mathrm{Mg}, \mathrm{Ca}$, and $\mathrm{Zr}$; the increase in these element indicates that the elements did not undergo decomposition during the carbonization process; on the other hand, if there was a decrease in the weight of elements such as $\mathrm{Na}, \mathrm{P}, \mathrm{Cl}$, and $\mathrm{Ca}$, this would show that the element decomposed during the carbonization process. Materials containing cellulose, hemicellulose, and lignin in the carbonization process using $500{ }^{\circ} \mathrm{C}$ temperatures can decompose and produce various products including tar, water vapor, carbon, and some others, such as $\mathrm{CO}, \mathrm{CO}_{2}, \mathrm{CH}_{2}$, and $\mathrm{H}_{2}$ gases.

\subsection{Activated Carbon Yield}

The yield of the carbonization process was generally charcoal with porosity and small surface area because it was still covered with hydrocarbon deposits. It had a less effective absorption capacity; therefore, the charcoal obtained after the carbonization process will be upgraded through the activation process. Among the important parameters during the active transfer of microalgae charcoal until the activated charcoal was activated charcoal yield. As shown in Figure 1, the yield value obtained from the largest was $19.28-66.51 \%$. The lowest yield was obtained by using an $\mathrm{H}_{3} \mathrm{PO}_{4}$ activator agent with a 
composition of $50 \%$ and the highest yield obtained by using a $\mathrm{ZnCl}_{2}$ activator agent with a composition of $50 \%$.

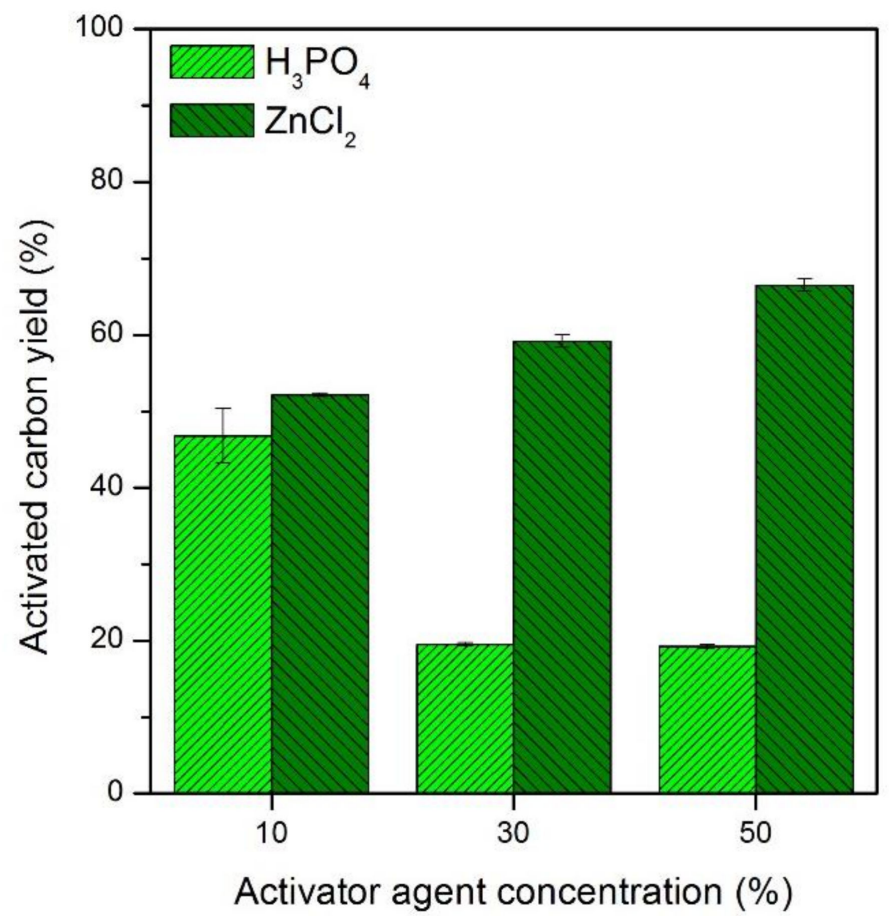

Figure 1. The yield of microalgae Chlorella vulgaris activated carbon.

The use of $\mathrm{H}_{3} \mathrm{PO}_{4}$ activator agents with increasing concentration tended to reduce the yield of activated carbon produced; this is because the composition possessed by microalgae allows for a more effective reaction with acid. In contrast to the use of activating agent $\mathrm{ZnCl}_{2}$, it was found that the increasing concentration of activating agents tended to increase the yield produced. This is due to the composition possessed by microalgae charcoal, which does not react effectively with activating agent $\mathrm{ZnCl}_{2}$, so that it still leaves $\mathrm{Zn}$ and $\mathrm{Cl}$ residue on activated carbon, which also gives a mass increase in microalgae activated carbon.

\subsection{Ash Content}

Analysis of ash content in activated carbon aimed to determine the content of metal oxides in activated carbon. The ash content was indicated as mineral residue that was still left behind during the carbonization process, because the microalgae biomass used as the raw material for activated carbon did not only contain carbon, but also mineral elements. Some minerals were lost during the carbonization and chemical activation process, but others were thought to remain in the activated carbon component. The ash content of activated charcoal was very influential on the activated carbon obtained. The presence of ash as a result of oxidation volatile components contained in activated carbon can cause clogging of activated carbon pores and will affect the surface area of activated carbon. As shown in Figure 2, the ash content from activation using $\mathrm{H}_{3} \mathrm{PO}_{4}$ activator agent ranged from 12.98-38.44\%, and activation using $\mathrm{ZnCl}_{2}$ ranged from $47.38-48.79 \%$. The highest ash content was obtained by using $\mathrm{ZnCl}_{2}$ activating agent at a concentration of $50 \%$, and the lowest ash content was obtained by treatment using the $\mathrm{H}_{3} \mathrm{PO}_{4}$ activating agent at a concentration of $30 \%$. Moreover, the value of the activated carbon ash content results of activation were still smaller than the non-treatment sample activation, which reached a value of $56.87 \%$. 
From the results obtained, it was shown that the $\mathrm{ZnCl}_{2}$ activator agent produced more ash content compared to using acid activator. This condition occurred because during the activation process, the components other than carbon contained in the microalgae charcoal reacted with activating agents used in this study, thus reducing the ash content of activated carbon, where ash content was accumulated mineral salts and metal elements that were still found in microalgae charcoal after the carbonization process. The ash content, which was relatively large, was thought to be due to the initial composition of the raw material and direct contact with the air, so that the carbonization process did not run perfectly, resulting in the formation of larger amounts of ash. The ash content of the activated carbon was produced from the oxidation reaction, which caused the adsorption to decrease, because the activated charcoal pore was covered by various minerals such as $\mathrm{Na}, \mathrm{Ca}, \mathrm{K}$, and $\mathrm{Mg}$, which were still attached to the surface of the activated charcoal. In a study conducted by [33], it was also known that the largest components found in activated carbon ash were $\mathrm{Ca}, \mathrm{Al}, \mathrm{Si}, \mathrm{Fe}$, and $\mathrm{S}$.

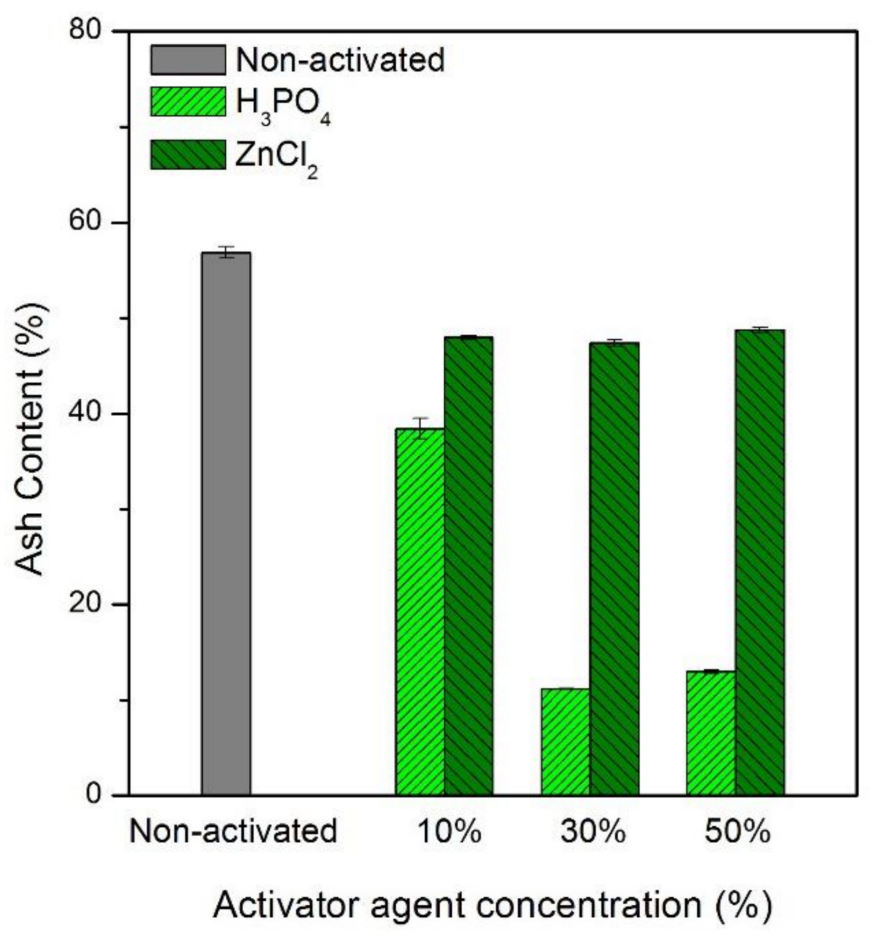

Figure 2. Ash content of microalgae Chlorella vulgaris activated carbon.

\subsection{Volatile Matter Content}

The levels of volatile matter content in activated carbon indicated evaporation of elements and non-carbon compounds. The level of substances that evaporated was the result of decomposition of constituent elements of activated carbon due to the heating process during the carbonization and activation process. Figure 3 shows the mean levels of the volatile matter of activated carbon of microalgae Chlorella vulgaris. 


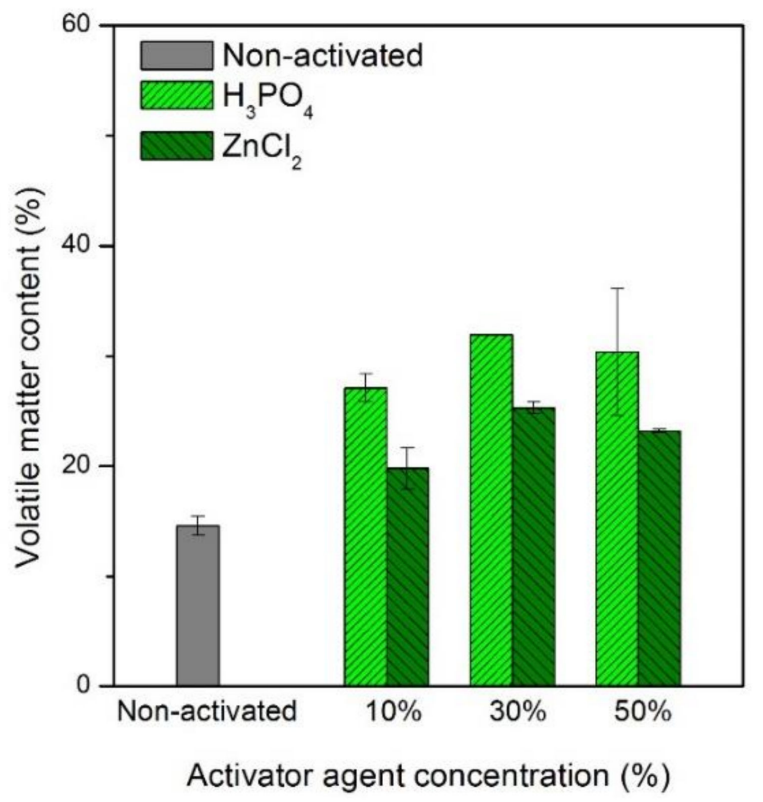

Figure 3. Volatile matter content of microalgae Chlorella vulgaris activated carbon.

The level of the vaporized substance of activated carbon as a result of activation using the $\mathrm{H}_{3} \mathrm{PO}_{4}$ activator agent ranged from $27.10-30.36 \%$, and activation using $\mathrm{ZnCl}_{2}$ ranged from $19.79-23.21 \%$. The highest levels of volatile substances were obtained by treatment using the $\mathrm{H}_{3} \mathrm{PO}_{4}$ activator agent at a concentration of $30 \%$, and the lowest levels of the evaporated substance were obtained by using the $\mathrm{ZnCl}_{2}$ activator agent at a concentration of $10 \%$. Vapor content values obtained from all treatments were generally greater than those of microalgae without activation treatment because after the activation process, micropores formed on the surface of activated carbon, and the resulting micropore was occupied by volatiles, which made the level of volatile substances from activated carbon activation results increasingly increase.

\subsection{Pure Activated Carbon Content}

The level of pure activated carbon was carbon that bound in the activated carbon other than the volatile substance fraction and ash content. Figure 4 shows the average levels of pure activated carbon of microalgae Chlorella vulgaris. The level of pure activated carbon from activation using the $\mathrm{H}_{3} \mathrm{PO}_{4}$ activating agent ranged from 34.46-56.66\%, and activation using $\mathrm{ZnCl}_{2}$ ranged from $27.99-32.24 \%$. The highest levels of pure activated carbon were obtained by treatment using the $\mathrm{H}_{3} \mathrm{PO}_{4}$ activator agent at a concentration of $50 \%$, and the lowest level of pure activated carbon was obtained by treatment using activator agent $\mathrm{ZnCl}_{2}$ at a concentration of $30 \%$. 


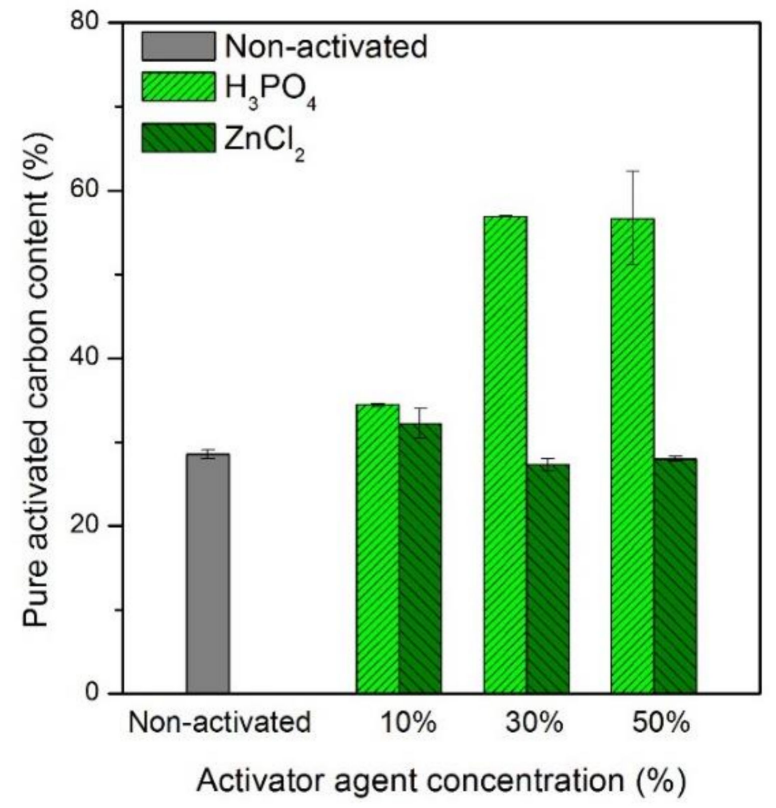

Figure 4. Pure activated carbon content of microalgae Chlorella vulgaris activated carbon.

From the data obtained, it was known that in general, the activation carried out was able to increase the content of pure activated carbon compared with microalgae charcoal without treatment, except in the activation process using $\mathrm{ZnCl}_{2}$ at concentrations of 30 and $50 \%$ obtained by the level of smaller pure activated carbon due to the content $\mathrm{ZnCl}_{2}$, which covered the pores of activated carbon. The content of pure activated carbon was influenced by the ash content, the level of the substance vaporized, and the presence of hydrocarbon compounds that were still attached to the activated carbon surface. The high level of bound carbon showed that the carbon fraction bound in activated carbon resulting from the activation process was getting higher.

\subsection{Iodine Absorption}

The iodine absorption test aimed to determine the ability of activated carbon to absorb colored solutions with a molecular size of less than $10 \AA$ or $1 \mathrm{~nm}$. Figure 5 shows the average absorption of iodine by activated carbon microalgae Chlorella vulgaris. Absorption of the iodine solution of activated carbon as a result of activation using the $\mathrm{H}_{3} \mathrm{PO}_{4}$ activating agent ranged from $256.15-330.39 \mathrm{mg} \mathrm{g}^{-1}$, and activation using $\mathrm{ZnCl}_{2}$ ranged from $192.09-230.31 \mathrm{mg} \mathrm{g}^{-1}$. The activation that had been done was able to increase the absorption of microalgae activated carbon against iodine solution. The results of the largest absorption of iodine solution were obtained by treatment using the $\mathrm{H}_{3} \mathrm{PO}_{4}$ activator agent at a concentration of $50 \%$.

High and low of iodine absorption refers to the number of micropores formed during the activation process. The greater iodine absorption indicates a greater number of micropores formed, or in other words, a greater surface of the activated carbon produced. The active absorption of charcoal was generally influenced by the nature of activated charcoal, the nature of the solution or components to be absorbed, and the contact system of the activated charcoal surface. The low absorption of iodine was generally caused by damage to or erosion of the pore surface of activated carbon, but the low absorption of iodine in this study was thought to be due to the large amount of impurities remaining after activation, which cover the pores of activated carbon and affect the ability of activated carbon to absorb iodine. 


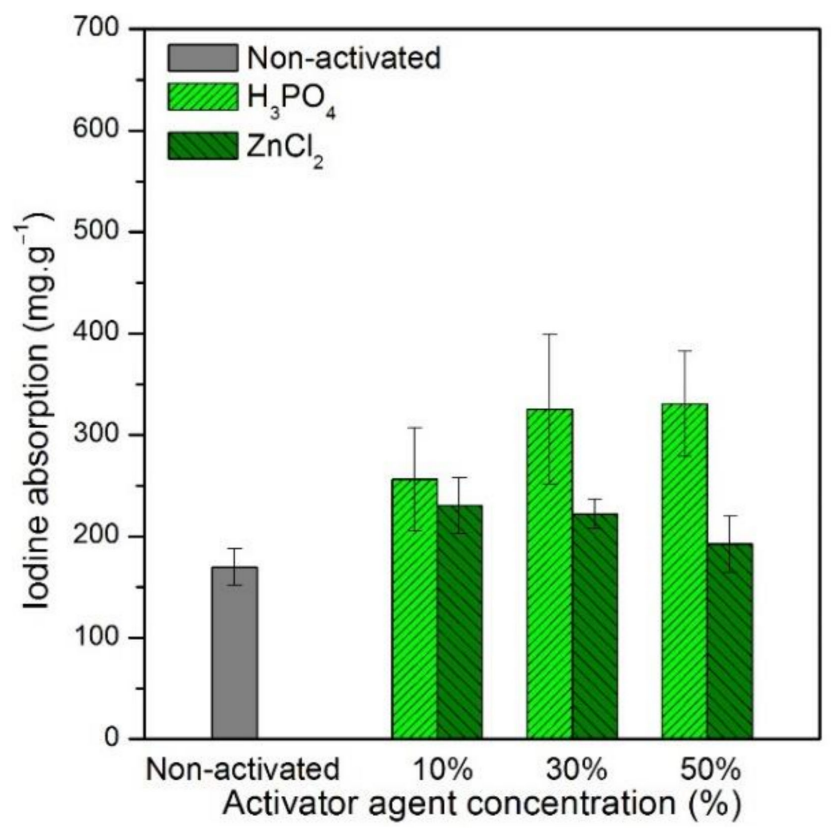

Figure 5. Iodine absorption of microalgae Chlorella vulgaris activated carbon.

\subsection{FTIR Analysis}

The FTIR spectra of non-activated Chlorella vulgaris dry raw mass powder and activated carbon prepared from $50 \% \mathrm{H}_{3} \mathrm{PO}_{4}$ and $10 \% \mathrm{ZnCl}_{2}$ are presented in the following Figure 6 .

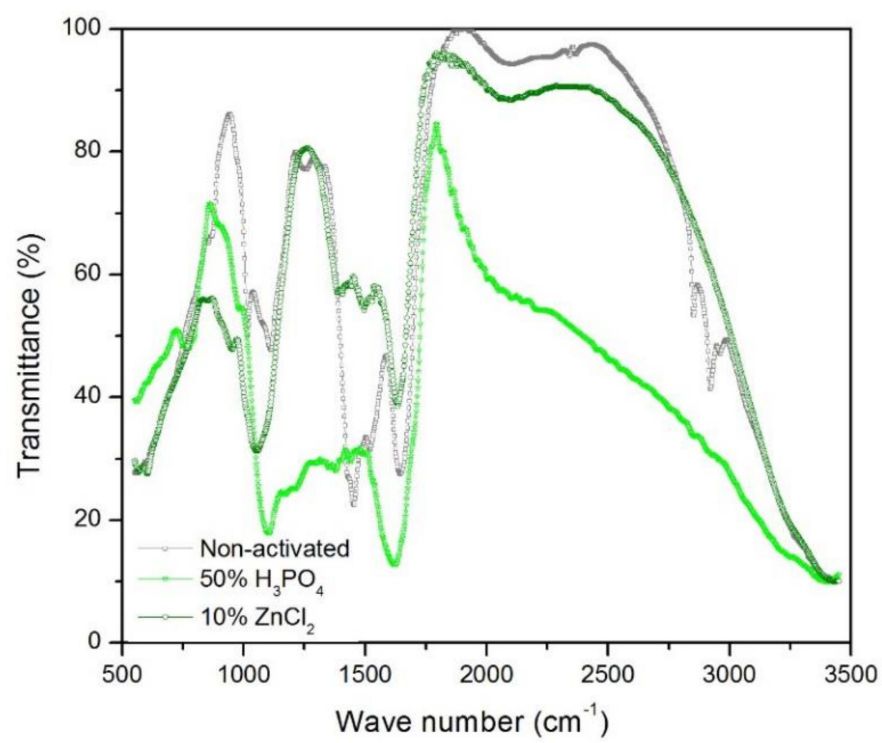

Figure 6. Fourier-transform infrared (FTIR) spectra of non-activated Chlorella vulgaris powder, $50 \%$ $\mathrm{H}_{3} \mathrm{PO}_{4}$ and $10 \% \mathrm{ZnCl}_{2}$ activation.

From the spectra obtained, it was known that biomass Chlorella vulgaris had a more complex bond than the activated carbon microalgae Chlorella vulgaris with activation of $50 \% \mathrm{H}_{3} \mathrm{PO}_{4}$ and $10 \% \mathrm{ZnCl}_{2}$. It is known that the activation process is able to decompose the complex bond in dry microalgae raw materials. The complete compounds of Chlorella vulgaris dry raw mass powder and activated carbon prepared from $50 \% \mathrm{H}_{3} \mathrm{PO}_{4}$ and $10 \% \mathrm{ZnCl}_{2}$ are listed in Table 2. 
Table 2. Comparison of the elemental composition of microalgae Chlorella vulgaris dry raw mass powder (non-activated) and activated carbon prepared from $50 \%$

$\mathrm{H}_{3} \mathrm{PO}_{4}$ and $10 \% \mathrm{ZnCl}_{2}$.

\begin{tabular}{|c|c|c|c|c|}
\hline \multicolumn{3}{|c|}{ Peak $\mathrm{cm}^{-1}$} & \multirow[b]{2}{*}{ Functional Group } & \multirow[b]{2}{*}{ Name } \\
\hline $\begin{array}{l}\text { C. vulgaris Powder } \\
\text { (Non-Activated) }\end{array}$ & $50 \% \mathrm{H}_{3} \mathrm{PO}_{4}$ & $10 \% \mathrm{ZnCl}_{2}$ & & \\
\hline 3426.10 & & & O-H stretching & alcohol \\
\hline & 3402.96 & & O-H stretching & alcohol \\
\hline 2922.72 & & & $\mathrm{C}-\mathrm{H}$ stretching & alkane \\
\hline 2853.29 & & & $\mathrm{C}-\mathrm{H}$ stretching & alkane \\
\hline \multirow[t]{3}{*}{1644.00} & & & $\mathrm{C}=\mathrm{N}$ stretching & imine/oxime \\
\hline & & 1634.36 & $\mathrm{C}=\mathrm{C}$ stretching, $\mathrm{N}-\mathrm{H}$ bending & Alkene, conjugated alkene, amine, cyclic alkene \\
\hline & 1622.79 & & $\mathrm{C}=\mathrm{C}$ stretching, $\mathrm{N}-\mathrm{H}$ bending & conjugated alkene, amine, cyclic alkene \\
\hline \multirow[t]{3}{*}{1516.71} & & & $\mathrm{~N}-\mathrm{O}$ stretching & nitro compound \\
\hline & & 1385.56 & $\mathrm{C}-\mathrm{H}$ bending & Aldehyde, alkane \\
\hline & 1379.77 & & $\mathrm{O}-\mathrm{H}$ bending, C-F stretching, $\mathrm{O}-\mathrm{H}$ bending & Alcohol, fluoro compound, phenol \\
\hline \multirow[t]{2}{*}{1254.41} & & & C-O stretching, C-O stretching & aromatic ester, alkyl aryl ether \\
\hline & 1208.12 & & $\begin{array}{l}\text { C-F stretching, C-O stretching, C-N stretching, } \\
\text { C-O stretching, C-O stretching }\end{array}$ & fluoro compound, alkyl aryl ether, amine, vinyl ether, ester \\
\hline \multirow[t]{3}{*}{1111.68} & & & C-N stretching, C-O stretching, C-O stretching & Amine, aliphatic ether, secondary alcohol \\
\hline & 1102.04 & & C-N stretching, C-O stretching, C-O stretching & Amine, aliphatic ether, secondary alcohol \\
\hline & & 1055.75 & $\mathrm{C}-\mathrm{O}$ stretching, $\mathrm{S}=\mathrm{O}$ stretching & primary alcohol, sulfoxide \\
\hline 1017.18 & & & C-F & \\
\hline \multirow[t]{5}{*}{868.67} & & & $\mathrm{C}-\mathrm{H}$ bending & 1,2,4-trisubstituted, 1,3-disubstituted \\
\hline & 774.16 & & $\mathrm{C}-\mathrm{H}$ bending & $\begin{array}{c}\text { 1,2,4-trisubstituted, 1,3-disubstituted, 1,4-disubstituted or } \\
\text { 1,2,3,4-tetrasubstituted, 1,2,3-trisubstituted }\end{array}$ \\
\hline & & 602.51 & $\mathrm{C}-\mathrm{Cl}$ stretching, $\mathrm{C}-\mathrm{Br}$ stretching & halo compound \\
\hline & & 567.80 & $\mathrm{C}-\mathrm{Cl}$ stretching, $\mathrm{C}-\mathrm{Br}$ stretching, C-I stretching & halo compound \\
\hline & 560.08 & & C-Cl stretching, C-Br stretching, C-I stretching & halo compound \\
\hline 554.29 & & & $\mathrm{C}-\mathrm{Cl}$ stretching, $\mathrm{C}-\mathrm{Br}$ stretching, C-I stretching & halo compound \\
\hline
\end{tabular}


The results revealed that a large amount of chemical functional groups $\mathrm{C} \equiv \mathrm{C}, \mathrm{C}=\mathrm{C},=\mathrm{CH}, \equiv \mathrm{CH}$, $\mathrm{C}-\mathrm{O}, \mathrm{C}=\mathrm{O}$ and $-\mathrm{COOH}$ were preserved and generated on the surface of activated carbon during the activation stage, which might enhance its adsorptive properties [34]. In a study conducted by [33], it was known that wavelengths between 1200 and $400 \mathrm{~cm}^{-1}$ in the FTIR spectrum are activated carbon ash, which indicate most mineral components.

\subsection{Surface Area and Pore Properties}

BET surface area testing was carried out on the sample with the best iodine absorption from each activator agent given, namely the $\mathrm{ZnCl}_{2} 10 \%$ and $\mathrm{H}_{3} \mathrm{PO}_{4} 50 \%$ treatment. Based on the $\mathrm{N}_{2}$ adsorption-desorption isotherm as shown in Figure 7, it can be known in general for activated carbon products that have a size smaller than $20 \AA$, which indicates that micropores were present in this adsorbent. The form of the isotherm in the activated product also showed a significant increase in the adsorption process at relative pressure because of the interaction of the high adsorbates, then reached the peak of the compilation, which showed the relative increase in activated carbon, which was fully filled. This type of isotherm is suitable for micropore adsorbents with pores no wider than $20 \AA$. This finding is consistent with the high ratio of the micropore volume of the micropore area and the BET surface area and total pore volume [35].

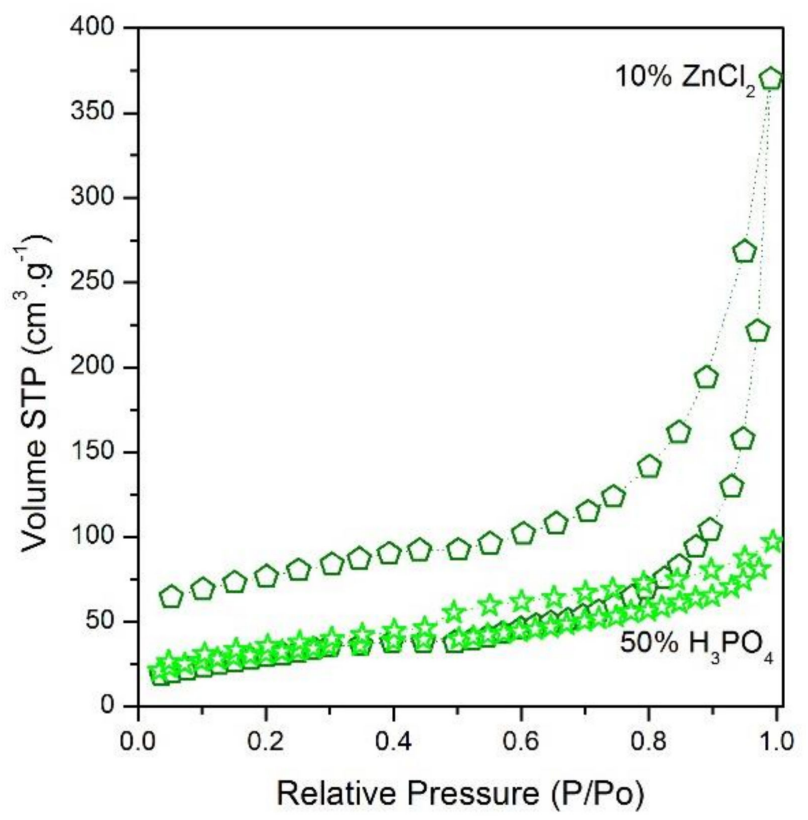

Figure 7. $\mathrm{N}_{2}$ adsorption-desorption isotherms of microalgae-based activated carbons.

The pore size of activated carbon was obtained using the $\mathrm{BJH}$ method using the carbon pore volume in the measurement of the $\mathrm{N}_{2}$ desorption isotherm. From the results of testing using the surface area analyzer, it was known that the BET surface area of the two sample samples was $115.352 \mathrm{~m}^{2} \mathrm{~g}^{-1}$ and $109.273 \mathrm{~m}^{2} \mathrm{~g}^{-1}$, respectively; while the average pore diameter was $1.985 \AA$ and $0.55 \AA$, respectively. The largest surface area will be obtained when the pore diameter is smaller in size and they are greater in number. The depiction of the average pore diameter with the pore surface area and pore volume formed is shown in Figures 8 and 9. 


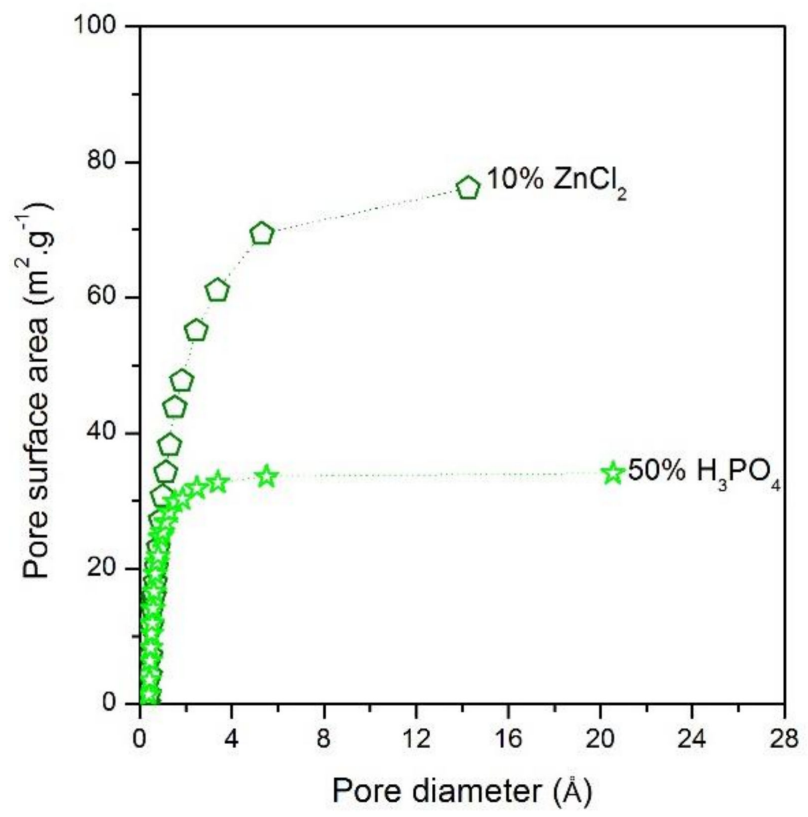

Figure 8. Pore diameter and pore surface area distribution of microalgae-based activated carbons.

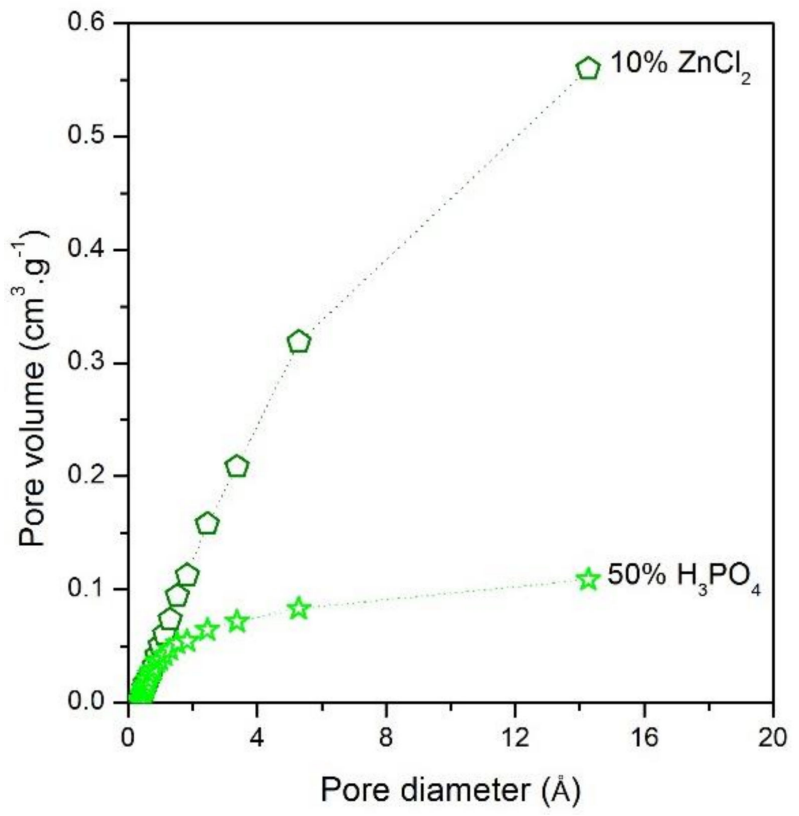

Figure 9. Pore diameter and pore volume distribution of microalgae-based activated carbons.

\subsection{Pore Structure and Elemental Composition}

The pore structure is very closely related to surface area, where the more active carbon pores will have an impact on the surface area of activated carbon and the greater the speed of adsorption. SEM imaging was focused on the sample with the highest iodine absorption from each activator agent, namely activated carbon from activation with $\mathrm{ZnCl}_{2} 10 \%$ and $50 \% \mathrm{H}_{3} \mathrm{PO}_{4}$ compared with dry microalgae powder as raw material, microalgae charcoal, and commercial activated carbon. The pore structure results of imaging using SEM are presented in Figure 10.

Figure 10 shows that the raw material of dry microalgae powder and charcoal from carbonization results showed different shapes due to decomposition during the carbonization process using a temperature of $500^{\circ} \mathrm{C}$, but on the surface, neither showed micropore formation. In contrast to activated charcoal that has gone through the activation process, in Figure 10b-d have addressed the formation of 
micropores, and this shows that the activation process using $\mathrm{ZnCl}_{2}$ and $\mathrm{H}_{3} \mathrm{PO}_{4}$ activator agents was able to create microporous surfaces of almost a uniform size so they can expand its surface.

As shown in Table 1, there was a change in the elemental composition of each step carried out: the carbonization process had increased the carbon, but also still contained elements in addition to carbon in sufficient quantities. The carbon results of activation using $\mathrm{ZnCl}_{2}$ showed a smaller carbon yield compared to the charcoal from activation, and this is presumably because the content of elements other than carbon remaining after the activation process covered the carbon surface, resulting in fewer readings of carbon elements in SEM-EDX analysis. The highest carbon content was obtained from the treatment using the $\mathrm{H}_{3} \mathrm{PO}_{4}$ activator agent with an elemental weight of $72.31 \%$. On activation by using $\mathrm{H}_{3} \mathrm{PO}_{4}, \mathrm{Na}, \mathrm{P}, \mathrm{Cl}, \mathrm{Ca}$, and $\mathrm{Zr}$ elements were found to decrease in number or even disappear; thus, it was known that acid activators were more able to react with microalgae charcoal. If this is related to the discussion of iodine absorption, it can be known that the absorption of iodine produced in this study was relatively lower compared to commercial activated carbon because the activated carbon surface was activated by an element other than carbon, so that the absorption capacity decreased. The results of this study are comparable to the reported results in [36], which for making activated carbon using chemical activation, a good activator used for lignocellulose material was to use an acid-type activator. This is because the lignocellulose material has a high oxygen content and causes the acid activator to react with a functional group containing oxygen, while the base activator tends to react with carbon, making it suitable for high carbon-containing materials.
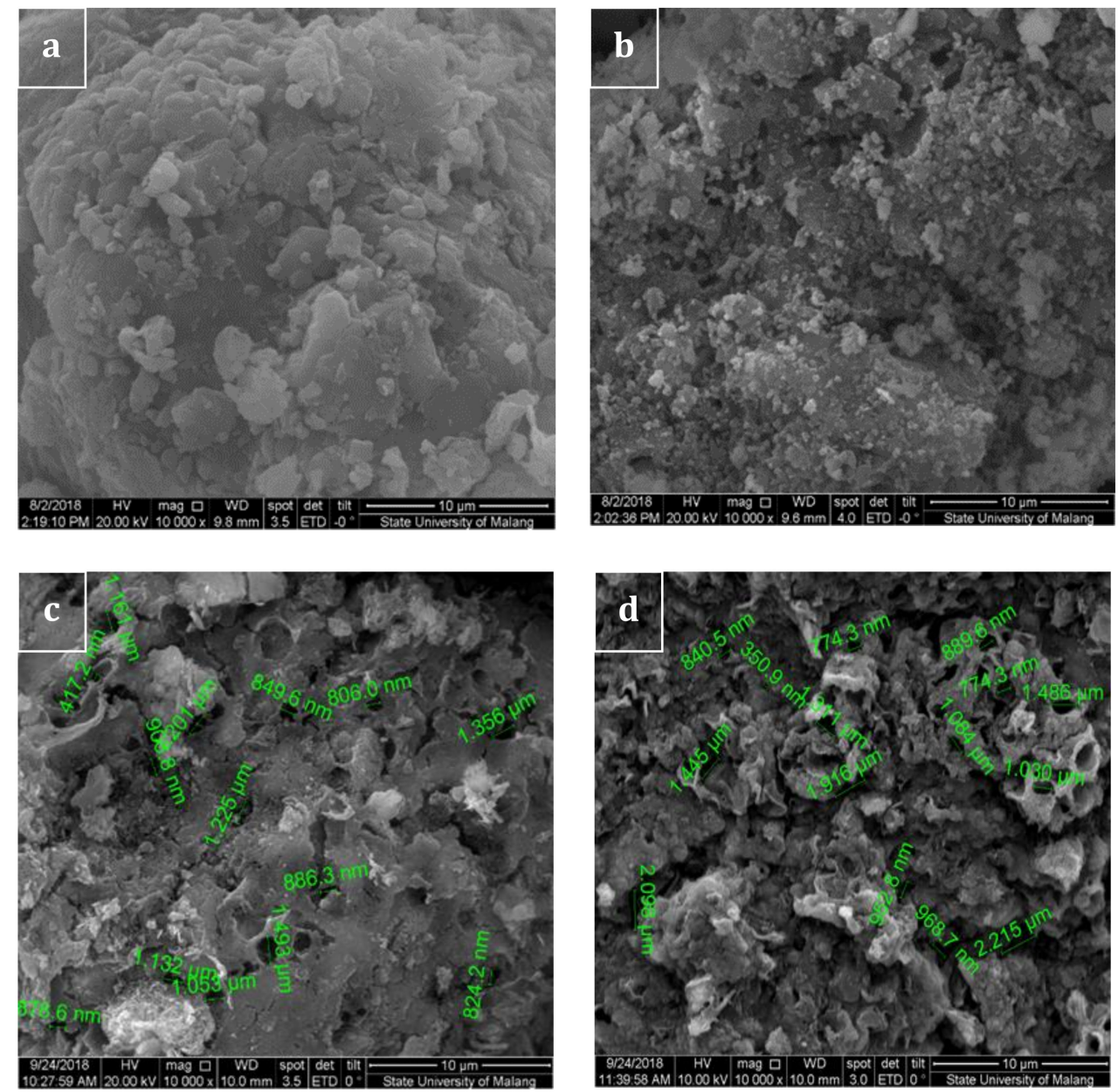

Figure 10. SEM-EDX images: (a) dry microalgae powder; (b) microalgae charcoal; (c) activated carbon results of activation with $10 \% \mathrm{ZnCl}_{2} ;$ (d) activated carbon from activation with $50 \% \mathrm{H}_{3} \mathrm{PO}_{4}$. 


\subsection{Future Direction of Research}

Although this study presented the potential of the production of activated carbon from microalgae, especially from Chlorella vulgaris, further studies are required. Thermal analysis of TG-DTG is needed to quantify the decomposition of biomass during heating. The analysis will give more insight into the elemental composition of activated carbon. Ash content for instance could be reduced when the optimum carbonization condition is known properly. Further application of activated carbon produced in this study, with hybridization in membrane materials, is also important to be done. By embedding the activated carbon as a filler in mixed matrix membrane, the real potency of microalgae-based activated carbon could be revealed more clearly.

\section{Conclusions}

Activation using $\mathrm{H}_{3} \mathrm{PO}_{4}$ and $\mathrm{ZnCl}_{2}$ with different concentrations accompanied by microwave irradiation had an effect on ash content, vaporized substance level, and pure activated carbon content of microalgae Chlorella vulgaris. Activation carried out was able to reduce the content of ash compared to microalgae charcoal without treatment, and the level of volatile substances tended to be higher because the pores of carbon were occupied by many volatile substances, while carbon content was generally higher than the charcoal without treatment, with the best results using acid activator. Activation using different $\mathrm{H}_{3} \mathrm{PO}_{4}$, and $\mathrm{ZnCl}_{2}$ with different concentrations was able to increase the absorption capacity of the iodine solution and enlarge the surface area due to micropore formation. Chlorella vulgaris microalgae can be used as a potential source for making activated carbon, with activation using 50\% $\mathrm{H}_{3} \mathrm{PO}_{4}$ and with microwave irradiation capable of increasing the carbon content to reach $72.31 \%$. Moreover, the powder activated carbon could be utilized as an absorber filling in a mixed matrix membrane for gas or liquid separation.

Author Contributions: Y.W. designed the concepts; A.S. was responsible for the experimentation processes; A.S. did the original draft preparation; Y.W. conducted the review and editing; both Y.W. and G.D. supervised the overall processes.

Funding: A.S. would like to thank the Indonesia Endowment Fund for Education (Lembaga Pengelola Dana Pendidikan/LPDP) for providing funding of the master thesis research grant.

Acknowledgments: The authors would like to thank the Ministry of Research, Technology and Higher Education, Republic of Indonesia.

Conflicts of Interest: The authors declare no conflict of interest.

\section{References}

1. Wibisono, Y. Biomaterial dan Bioproduk (in Bahasa Indonesia); UB Press: Malang, Indonesia, 2017; pp. $22-27$.

2. Ulfyana, D.; Anugroho, F.; Sumarlan, S.H.; Wibisono, Y. Bioceramics synthesis of hydroxyapatite from red snapper fish scales biowaste using wet chemical precipitation route. IOP Conf. Ser. Earth Environ. Sci. 2018, 131, 012038. [CrossRef]

3. Wibisono, Y.; Dwijaksara, N.L.B.; Widayatno, W.B.; Wismogroho, A.S.; Amal, M.I.; Rochman, N.T.; Nishimura, T.; Noviyanto, A. Synthesis and sinterability of hydroxyapatite from fishery by-products. J. Korean Ceram. Soc. 2018, 55, 570-575. [CrossRef]

4. Brown, R.C.; Brown, T.R. Biorenewable Resources-Engineering New Products from Agriculture, 2nd ed.; John Wiley \& Sons: Oxford, UK, 2014.

5. Devianto, L.A.; Aprilia, D.N.; Indriani, D.W.; Sukarni, S.; Sumarlan, S.H.; Wibisono, Y. Marine microalge Nannochloropsis oculata biomass harvesting using ultrafiltration in cross-flow mode. IOP Conf. Ser. Earth Environ. Sci. 2018, 131, 012042. [CrossRef]

6. Yan, C.; Zhu, L.; Wang, Y. Photosynthetic $\mathrm{CO}_{2}$ uptake by microalgae for biogas upgrading and simultaneously biogas slurry decontamination by using of microalgae photobioreactor under various light wavelengths, light intensities, and photoperiods. Appl. Energy 2016, 178, 9-18. [CrossRef]

7. Cheah, W.Y.; Show, P.L.; Chang, J.S.; Ling, T.C.; Juan, J.C. Biosequestration of atmospheric $\mathrm{CO}_{2}$ and flue gas-containing $\mathrm{CO}_{2}$ by microalgae. Bioresour. Technol. 2015, 184, 190-201. [CrossRef] [PubMed] 
8. Jiang, L.; Luo, S.; Fan, X.; Yang, Z.; Guo, R. Biomass and lipid production of marine microalgae using municipal wastewater and high concentration of $\mathrm{CO}_{2}$. Appl. Energy 2011, 88, 3336-3341. [CrossRef]

9. Vanthoor-Koopmans, M.; Wijffels, R.H.; Barbosa, M.J.; Eppink, M.H.M. Biorefinery of microalgae for food and fuel. Bioresour. Technol. 2013, 135, 142-149. [CrossRef] [PubMed]

10. Yen, H.W.; Hu, I.C.; Chen, C.Y.; Ho, S.H.; Lee, D.J.; Chang, J.S. Microalgae-based biorefinery-From biofuels to natural products. Bioresour. Technol. 2013, 135, 166-174. [CrossRef] [PubMed]

11. Zhu, Y.; Albrecht, K.O.; Elliott, D.C.; Hallen, R.T.; Jones, S.B. Development of hydrothermal liquefaction and upgrading technologies for lipid-extracted algae conversion to liquid fuels. Algal Res. 2013, 2, 455-464. [CrossRef]

12. Wang, K.; Brown, R.C.; Homsy, S.; Martinez, L.; Sidhu, S.S. Fast pyrolysis of microalgae remnants in a fluidized bed reactor for bio-oil and biochar production. Bioresour. Technol. 2013, 127, 494-499. [CrossRef]

13. Alzate, M.E.; Munoz, R.; Rogalla, F.; Fdz-Polanco, F.; Perez-Elvira, S.I. Biochemical methane potential of microalgae biomass after lipid extraction. Chem. Eng. J. 2014, 243, 405-410. [CrossRef]

14. Abobaker, M.S.A.; Anggunsari, R.; Nurlailati, S.; Susilo, B.; Dewi, S.R.; Wibisono, Y. Design and performance of bioreactor for fermentative biogas production from marine microalgae. IOP Conf. Ser. Earth Environ. Sci. 2019, 230, 012009. [CrossRef]

15. Ramos-Suarez, J.L.; Carreras, N. Use of microalgae residues for biogas production. Chem. Eng. J. 2014, 242, 86-95. [CrossRef]

16. Cheng, J.; Huang, R.; Yu, T.; Li, T.; Zhou, J.; Cen, K. Biodiesel production from lipids in wet microalgae with microwave irradiation and bio-crude production from algal residue through hydrothermal liquefaction. Bioresour. Technol. 2014, 151, 415-418. [CrossRef]

17. Wibisono, Y. Two-Phase Flow for Fouling Control in Membranes. Ph.D. Thesis, University of Twente, Enschede, The Netherlands, 2014; p. 250.

18. Wibisono, Y.; Ahmad, F.; Cornelissen, E.R.; Kemperman, A.J.B.; Nijmeijer, K. Dominant factors controlling the efficiency of two-phase flow cleaning in spiral-wound membrane elements. Desalin. Water Treat. 2016, 57, 17625-17636. [CrossRef]

19. Eltom, A.E.; Lessa, M.P.F.; da Silva, M.J.; da Rocha, J.C. Production and characterization of activated carbon membranes. J. Mater. Res. Technol. 2012, 1, 80-83. [CrossRef]

20. Utoro, P.A.R.; Sukoyo, A.; Sandra, S.; Izza, N.; Dewi, S.R.; Wibisono, Y. High-throughput microfiltration membranes with natural biofouling reducer agent for food processing. Processes 2019, 7, 1. [CrossRef]

21. Hosseini, S.M.; Amini, S.H.; Khodabakhshi, A.R.; Bagheripour, E.; van der Bruggen, B. Activated carbon nanoparticle entrapped mixed matrix polyethersulfone based nanofiltration membrane for sulfate and copper removal from water. J. Taiwan Inst. Chem. Eng. 2018, 82, 169-178. [CrossRef]

22. Zhao, L.H.; Wu, C.R.; Lu, X.L.; Ng, D.; Truong, Y.B.; Xie, Z.L. Activated carbon enhance hydrophobic/ hydrophilic dual layer nanofiber composite membranes for high-performance direct contact membrane distillation. Desalination 2018, 446, 59-69. [CrossRef]

23. Liu, Q.; Huang, S.; Zhang, Y.; Zhao, S. Comparing the antifouling effects of activated carbon and $\mathrm{TiO}_{2}$ in ultrafiltration membrane development. J. Coll. Interfaces Sci. 2018, 515, 109-118. [CrossRef]

24. Aghili, F.; Ghoreyshi, A.A.; Rahimpour, A.; Rahimnejad, M. Coating of mixed-matrix membranes with powdered activated carbon for fouling control and treatment of dairy effluent. Process Saf. Environ. 2017, 107, 528-539. [CrossRef]

25. Anson, M.; Marchese, J.; Garis, E.; Ochoa, N.; Pagliero, C. ABS copolymer-activated carbon mixed matrix membranes for $\mathrm{CO}_{2} / \mathrm{CH}_{4}$ separation. J. Membr. Sci. 2004, 243, 19-28. [CrossRef]

26. Heidari, M.; Hosseini, S.S.; Nasrin, M.O.; Ghadimi, A. Synthesis and fabrication of adsorptive nanoparticles (ACNs)/PDMS mixed matrix membranes for efficient $\mathrm{CO}_{2} / \mathrm{CH}_{4}$ and $\mathrm{C}_{3} \mathrm{H}_{8} / \mathrm{CH}_{4}$ separation. Sep. Purif. Technol. 2019, 209, 503-515. [CrossRef]

27. Weigelt, F.; Georgopanos, P.; Shishatskiy, S.; Filiz, V.; Brinkmann, T.; Abetz, V. Development and Characterization of Defect-Free Matrimid ${ }^{\circledR}$ Mixed-Matrix Membranes Containing Activated Carbon Particles for Gas Separation. Polymers 2018, 10, 51. [CrossRef] [PubMed]

28. Amaral, R.A.; Habert, A.C.; Borges, C.P. Activated carbon polyurethane membrane for a model fuel desulfurization by pervaporation. Mater. Lett. 2014, 137, 468-470. [CrossRef] 
29. Wibisono, Y.; Sucipto, S.; Perdani, C.G.; Astuti, R.; Dahlan, M. Halal compliance on drinking water industries: A future perspective. In Proceedings of the 3rd International Halal Conference (INHAC2016); Muhammad, H.N., Md Shariff, N., Mahamood, S., Fathullah, H.H., Shahruddin, M., Bhari, A., Eds.; Springer: Singapore, 2018.

30. Ao, W.; Fu, J.; Mao, X.; Kang, Q.; Ran, C.; Liu, Y.; Gao, Z.; Li, J.; Liu, G.; Dai, J. Microwave assisted preparation of activated carbon from biomass: A review. Renew. Sustain. Energy Rev. 2018, 92, 958-979. [CrossRef]

31. Thommes, M.; Kaneko, K.; Neimark, A.V.; Oliver, J.P.; Rodriguez-Reinoso, F.; Rouquerol, J.; Sing, K.S.W. Physisorption of gases, with special reference to the evaluation of surface area and pore size distribution. Pure Appl. Chem. 2015, 87, 1051-1069. [CrossRef]

32. Rizzo, A.M.; Prussi, M.; Bettucci, L.; Libelli, I.M.; Chiaramonti, D. Characterization of microalga Chlorella as a fuel and its thermogravimetric behavior. Appl. Energy 2013, 102, 24-31. [CrossRef]

33. Rodríguez, N.H.; Martínez-Ramírez, S.; Blanco-Varela, M.T. Activated carbon as an alternative fuel. Effect of carbon ash on cement Clinkerization. J. Clean. Prod. 2016, 119, 50-58. [CrossRef]

34. Zhou, L.; Yu, Q.; Cui, Y.; Xie, F.; Li, W.; Li, Y.; Chen, M. Adsorption properties of activated carbon from reed with a high adsorption capacity. Ecol. Eng. 2017, 102, 443-450. [CrossRef]

35. Chang, Y.M.; Tsai, W.T.; Li, M.H. Characterization of activated carbon prepared from chlorella-based algal residue. Bioresour. Technol. 2015, 184, 344-348. [CrossRef] [PubMed]

36. Hsu, L.Y.; Teng, H. Influence of different chemical reagent on the preparation of activated carbon from bituminous coal. Fuel Process. Technol. 2000, 64, 155-166. [CrossRef]

(C) 2019 by the authors. Licensee MDPI, Basel, Switzerland. This article is an open access article distributed under the terms and conditions of the Creative Commons Attribution (CC BY) license (http://creativecommons.org/licenses/by/4.0/). 